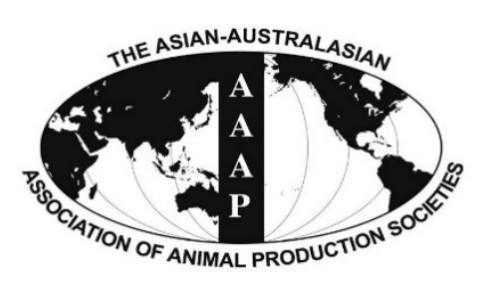

Open Access

Asian Australas. J. Anim. Sci.

Vol. 29, No. 12 : 1734-1741 December 2016

http://dx.doi.org/10.5713/ajas.16.0281

www.ajas.info

pISSN 1011-2367 elSSN 1976-5517

\title{
Improvement of Milk Fatty Acid Composition for Production of Functional Milk by Dietary Phytoncide Oil Extracted from Discarded Pine Nut Cones (Pinus koraiensis) in Holstein Dairy Cows
}

\author{
Min Jeong Kim, U Suk Jung, Seung Woo Jeon, Jae Sung Lee ${ }^{1}$, Won Seob Kim ${ }^{1}$, Sang Bum Lee ${ }^{2}$, \\ Youn Chil Kim², Bae Young Kim³ ${ }^{3}$ Tao Wang ${ }^{4}$, and Hong Gu Lee ${ }^{1, *}$ \\ Department of Animal Science and Technology, College of Animal Bioscience and Technology, \\ Konkuk University, Seoul 05029, Korea
}

\begin{abstract}
This study was conducted to examine the effects of adding phytoncide oil extracted from Korean pine nut cone byproduct to the diet of dairy cows on milk yield and compositions, fatty acid characteristics, complete blood count and stress response. A total of 74 Holstein cows were used for 30 days and divided into two groups. Each group was given a basal diet (C) or an experimental diet containing phytoncide additives at $0.016 \%(\mathrm{~T})$ in feed. The results showed that phytoncide feeding had no effect on milk yield. In addition, there were no observed effects on milk composition, but the ratio of fatty acid in milk was significantly affected by the phytoncide diet, and it showed a positive effect. Not only were the major functional fatty acids, conjugated linoleic acid and eicosapentaenoic acid increased, but also $\omega 6: \omega 3$ fatty acid ratio was reduced in milk of $\mathrm{T}$ group ( $\mathrm{p}<0.05$ ). In blood analysis, the complete blood count showed no significant difference between $\mathrm{C}$ and $\mathrm{T}$ group on all parameters. However, the cortisol concentration was significantly decreased in $\mathrm{T}$ group compared to control $(\mathrm{p}<0.05)$. Taken together, we suggest that phytoncide oil does not have a great influence on the physiological changes, but can be a potential feed additive that improves the milk fatty acid and stress resilience in dairy cows. In addition, it will contribute to the development of feed resource, a reduction in feed cost and a lessening of environmental pollution. (Key Words: Dairy Cow, Fatty Acids, Feed Additive, Milk, Phytoncide Oil)
\end{abstract}

\section{INTRODUCTION}

The use of antibiotic growth promoters has proven to be a useful means of improving feed efficiency (Yang et al., 2007). However, the usage of antibiotics has already been banned. Accordingly, both locally and abroad, substances that can be used as substitutes for a number of antibiotics

\footnotetext{
* Corresponding Author: Hong Gu Lee. Tel: +82-2-450-0523, Fax: +82-2-455-1044, E-mail: hglee66@konkuk.ac.kr

${ }^{1}$ Team of An Educational Program for Specialists in Global Animal Science, Brain Korea 21 Plus Project, Konkuk University, Seoul 05029, Korea.

${ }^{2}$ Green Filed EM Bio Feed Co., Ltd., Yangsan 50565, Korea.

${ }^{3}$ PHYLUS Co., Ltd., Danyang 27000, Korea.

${ }^{4}$ College of Animal Science and Technology, Jilin Agricultural University, Jilin 130118, China.

Submitted Apr. 8, 2016; Revised May 16, 2016; Accepted Jun. 26, 2016
}

have been developed. Among the various alternatives, the use of phytogenic materials in livestock production has greatly increased. We have chosen a natural material for our study. Phytoncide or essential oil is a natural substance and a food by-product derived from Korean origin pine nut cone. Currently, South Korea produces 2,435 tons of pine nuts annually, which are widely distributed to other Asian countries such as Japan and China. After pine nut cones are harvested, only nuts are used as the edible part, and the other by-products thrown away. As this waste by-product might cause environmental pollution, the utilization of discarded pine by-product extract is an efficient use of resources that would have been wasted otherwise.

In addition, pine resin contains terpenoid, phenols, tannins and alkaloids components. These secondary metabolites are materials produced from specific metabolism in certain species, which have antibacterial and 
insecticidal effects (Abe et al., 2008). Due to its various biological properties, this natural product is considered suitable for use as an alternative material.

Essential oils are complex mixtures of secondary metabolites and volatile compounds extracted from plants through distillation methods. Such plant-derived essential oils are means of improving the feed efficiency and health of dairy cattle (Yang et al., 2007). Plant extracts stimulate the immune system, thereby enhancing the resistance to inflammatory and infectious diseases. The study of Concha et al. (1996) showed that ginseng root extract stimulated neutrophils and lymphocytes from bovine peripheral blood and milk (Yang et al., 2007). Also, phytoncide exposure decreased stress hormone levels, because it also contributed to the activity of natural killer (NK) cells, a type of cytotoxic lymphocyte (Li, 2010).

Some studies have investigated the effects of essential oil or their components on digestion, ruminal fermentation, milk composition and milk production in dairy cows (Benchaar et al., 2007). As well, Benchaar et al. (2007) reported a change in the milk fatty acid profile when cows were supplemented daily with a mixture of essential oil compounds. Supplementing the mixture at a higher concentration increased the concentration of conjugated linoleic acid (CLA), a health-promoting fatty acid in milk fat (Benchaar et al., 2006). Among the different effective ingredients of milk, CLA is particularly important, as it has many positive health effects including anti-tumor effects (Igal, 2011), anti-atherosclerosis effects (Lee and Vanden Heuvel, 2010) and anti-diabetic effects (Moloney et al., 2007).

However, knowledge is still rather limited regarding the effects of pine-derived phytoncide on livestock. Therefore, the objective of this study was to investigate the effects of phytoncide extracted from discarded Korean pine nut cones on milk fatty acid composition and mitigation of stress in dairy cows.

\section{MATERIALS AND METHODS}

\section{Experimental materials and procedures}

Animals and design: To conduct the feeding experiment, a total of 74 Holsteins (mean $35 \mathrm{~kg}$ milk yield, 644 day lactation cycle and 2.5 calving number) were randomly assigned to two groups and studied for 30 days. All experimental procedures involving animals were performed according to the Animal Experimental Guidelines provided by the Animal Care and Use Committee of Konkuk University, Republic of Korea.

Diets and treatments: Dairy cows were fed total mixed ration $(86.9 \%)$, roughage $(3.9 \%)$, and concentrated feed (9.2\%). The experimental diets were formulated to meet or exceed the NRC recommendations (NRC, 2001) and were provided for ad libitum intake. Ingredient and chemical composition of experimental diet are presented in Table 1. Equal portions of feed and water were given to cows, and the diet was available at all times.

We received a phytoncide oil preparation from PHYLUS Co., Ltd. Essential oil was obtained by watervapor methods. Briefly after removing the pine nuts, pine nut cones were dried in the shade and the by-products were cut in 2 to $3 \mathrm{~cm}$ size. Pine nut cones were added into a $1,000 \mathrm{~mL}$ round flask and homogenized with distilled water $(0.5 \mathrm{~g} / 500 \mathrm{~mL}$ of water) for 1 to $2 \mathrm{~min}$, and distilled by steam distillation process $\left(100^{\circ} \mathrm{C} \pm 3^{\circ} \mathrm{C}, 3 \mathrm{~h}\right)$. After cooling the extract $\left(20^{\circ} \mathrm{C}\right)$, the pine nut cones extract (phytoncide essential oil) was separated from water using the difference in specific gravity. Then, the extract was filtrated and concentrated $\left(60^{\circ} \mathrm{C}, 100 \mathrm{mHg}\right)$. Finally, the extract was sealed and stored at $4^{\circ} \mathrm{C}$.

The chemical composition of phytoncide oil was analyzed using Gas Chromatograph/Mass Spectrometer (6890N series GC/MSD System, Agilent Technologies, Palo Alto, CA, USA). The analysis conditions are as follows.

Column: Phenomenex Zebron ZB-5ms (dimension: 30 meter $\times 0.25 \mathrm{~mm} \times 0.25 \mu \mathrm{m}$ ); injection: split $50: 1$, heater $255^{\circ} \mathrm{C}$, injection volume $1.0 \mu \mathrm{L}$, carrier gas: helium 1.0 $\mathrm{mL} / \mathrm{min}$; oven program: $40^{\circ} \mathrm{C}$ to $300^{\circ} \mathrm{C}, 5 / \mathrm{min}$; detector: MS System, heater $280^{\circ} \mathrm{C}$.

The main components of the essential oil were gammaTerpinene (26.8\%), dl-Limonene (19.6\%), beta-Pinene $(16.2 \%)$, and Isolongifolene (4.2\%) (Table 2). Phytoncide feed additive consists of rice bran $60 \%$ and corn grit $40 \%$ as excipients. Phytoncide oil was mixed with the vehicle at a $10 \%$ concentration and it was added to the basal diet at a final concentration of $0.016 \%$ by top dressing. The control group was fed the same amount of added the vehicle (not included phytoncide oil).

Milk sampling: During the experimental period, we collected milk twice a day, at 4 am and at $4 \mathrm{pm}$. The total milk yield was then calculated, and the mean for 10 days was measured. At the end of the period, average milk yield was calculated. After mixing the collected milk in the morning and afternoon, the samples were stored at $4^{\circ} \mathrm{C}$ for fatty acid analysis. Milk composition was measured with MilkoScan (CombiFoss FT+500 S/H, Hillerød, Denmark). Levels of milk fat, milk protein, solid-not-fat (SNF), somatic cells, milk urea nitrogen (MUN), and betahydroxybutyrate were analyzed at $0 \mathrm{~d}, 10 \mathrm{~d}, 20 \mathrm{~d}$, and $30 \mathrm{~d}$.

\section{Analysis}

Chemical analyses: Feed samples were analyzed for dry matter (DM), crude protein, ether extract, crude fiber, crude ash, neutral detergent fiber (NDF) and acid detergent fiber (ADF) according to AOAC (1990) procedures. DM content was determined by drying samples in a vacuum oven at 
Table 1. Ingredient and chemical composition of the experimental diet

\begin{tabular}{|c|c|c|c|c|}
\hline \multirow{2}{*}{ Item } & \multicolumn{4}{|c|}{ Diets } \\
\hline & Concentrates $(9.2 \%)$ & Roughage $(3.9 \%)$ & TMR $(86.9 \%)$ & Phytoncide additive (Vehicle) \\
\hline \multicolumn{5}{|l|}{ Ingredient (\%) } \\
\hline Canola seed meal & 9.00 & & & \\
\hline Coconut kernel meal & 6.00 & & & \\
\hline Corn & 20.00 & & & \\
\hline Corn gluten feed & 13.60 & & 5.00 & \\
\hline Dicalcium phospate & 0.20 & & & \\
\hline Limestone & 1.50 & & & \\
\hline $\mathrm{MgO}$ & 0.20 & & & \\
\hline Molasses & 6.00 & & 1.50 & \\
\hline Parm kernel meal & 14.20 & & 1.00 & \\
\hline Salt & 0.50 & & & \\
\hline Sesame seed meal & 2.00 & & & \\
\hline Sodium bicarbonate & 0.40 & & & \\
\hline Soybean meal & 10.00 & & 2.00 & \\
\hline Tallow & 2.00 & & & \\
\hline Tapioca & 3.00 & & & \\
\hline Vitamin mineral premix ${ }^{1}$ & 0.40 & & & \\
\hline Wheat middling & 11.00 & & & \\
\hline Canola seed meal & 9.00 & & & \\
\hline Tall fescue hay & & 100 & & \\
\hline Alfalfa hay & & & 6.50 & \\
\hline Beet pulp & & & 2.50 & \\
\hline Concentrate & & & 18.00 & \\
\hline Corn flake & & & 9.00 & \\
\hline Cotton seed & & & 5.00 & \\
\hline Klein grass hay & & & 5.00 & \\
\hline Oaten hay & & & 13.00 & \\
\hline Timothy hay & & & 2.50 & \\
\hline Rice bran & & & & 60 \\
\hline Corn grit & & & & 40 \\
\hline \multicolumn{5}{|l|}{ Chemical composition } \\
\hline DM (\%) & 88.72 & 92.36 & 62.46 & - \\
\hline Crude protein $(\%$ of DM $)$ & 19.6 & 5.62 & 9.61 & 11.26 \\
\hline Ether extract $(\%$ of DM) & 4.75 & 1.44 & 3.71 & 8.74 \\
\hline Crude fiber $(\%$ of DM) & 8.54 & 39.34 & 15.68 & 4.78 \\
\hline Crude ash (\% of DM) & 8.46 & 5.11 & 4.86 & 4.50 \\
\hline NDF ( $\%$ of DM) & 25.66 & 72.96 & 29.52 & - \\
\hline $\mathrm{ADF}(\%$ of $\mathrm{DM})$ & 11.1 & 43.6 & 18.08 & - \\
\hline $\mathrm{Ca}(\%$ of $\mathrm{DM})($ & 1.27 & 0.17 & 0.52 & 0.12 \\
\hline $\mathrm{P}(\%$ of $\mathrm{DM})$ & 0.64 & 0.14 & 0.27 & 1.00 \\
\hline $\mathrm{NE}_{\mathrm{L}}(\mathrm{Mcal} / \mathrm{kg} \text { of } \mathrm{DM})^{2}$ & 2.10 & 2.08 & 2.15 & 2.32 \\
\hline
\end{tabular}

TMR, total mixed ration; DM, dry matter; NDF, neutral detergent fiber; ADF, acid detergent fiber; ME, metabolizable energy; $\mathrm{NE}_{\mathrm{L}}$, net energy value of feeds for lactation.

${ }^{1}$ Vitamin mineral premix: Vit. A 1,000,000 IU; Vit. D 3 100,000 IU; Vit. E 25,000 mg; I 150 mg; Co 150 mg; Cu 2,500 mg; Fe 6,250 mg; Mn 16,000 mg; Zn 10,000 mg; Se $150 \mathrm{mg}$.

${ }^{2} \mathrm{NE}_{\mathrm{L}}, \mathrm{Mcal} / \mathrm{kg}$ of DM was estimated based on NRC (2001).

$100^{\circ} \mathrm{C}$ overnight. Ash content was determined by using the Fibertec Systems (Fibertec 2010, FOSS, incineration at $550^{\circ} \mathrm{C}$ overnight in a muffle furnace. Crude Denmark). Ether extract contents were obtained using the protein $(\mathrm{N} \times 6.25)$ was determined using the Kjeltec System ether extraction system (ANKOM XT15 Extractor, (Kjeltec 2400, FOSS, Hillerød, Denmark). Crude fiber, ANKOM Technology, NY, USA), and mineral contents of NDF and ADF content of the feed samples were analyzed the feed were determined by inductively coupled plasma 
Table 2. Major composition of terpenes in phytoncide oil ${ }^{1}$

\begin{tabular}{llc}
\hline No. & Item & \% of total \\
\hline 1 & gamma-Terpinene & 26.79 \\
2 & Camphene & 3.47 \\
3 & beta-Pinene & 16.15 \\
4 & dl-Limonene & 19.60 \\
5 & alpha-Terpinolene & 2.40 \\
6 & Bornyl acetate & 2.38 \\
7 & alpha-Longipinene & 1.79 \\
8 & Copaene & 2.35 \\
9 & Isolongifolene & 4.15 \\
10 & Caryophyllene & 3.45 \\
\hline
\end{tabular}

${ }^{1}$ And 40 other minority components, etc.

optical emission spectrometry (ICP-OES, Thermo, Waltham, MA, USA).

Fatty acid analysis using gas chromatography: Lipid was extracted using chloroform and methanol (Folch et al., 1957). FAME Mix STANDARD (Sigma-Aldrich/47885-U, St. Louis, MO, USA) was the standard for fatty acid content and fatty acid ratio. The measurement equipment was Gas Chromatograph/FID (HP 6890 series GC System, Agilent technologies, USA), and the analysis conditions are as follows.

Column: Sp-2560 Capillary column (dimension: 100 meter $\times 0.25 \mathrm{~mm} \times 0.2 \mu \mathrm{m}$, film thickness); injection: split $30: 1$, heater $255^{\circ} \mathrm{C}$, pressure: 32.64 , total flow: 39.5 $\mathrm{mL} / \mathrm{min}$, split flow: $36.0 \mathrm{~mL} / \mathrm{min}$, injection volume $1.0 \mu \mathrm{L}$, carrier gas: helium $1.2 \mathrm{~mL} / \mathrm{min}$; oven program: $70^{\circ} \mathrm{C}$ to $100^{\circ} \mathrm{C}$ : $5 / \mathrm{min}$ (Hold: $2 \mathrm{~min}$ ), $100^{\circ} \mathrm{C}$ to $175^{\circ} \mathrm{C}: 10 / \mathrm{min}$ (hold $40 \mathrm{~min}$ ), $175^{\circ} \mathrm{C}$ to $225^{\circ} \mathrm{C}: 5 / \mathrm{min}$ (hold $40 \mathrm{~min}$ ); detector: FID System, heater $260^{\circ} \mathrm{C}\left(\mathrm{H}_{2}\right.$ flow: $40 \mathrm{~mL} / \mathrm{min}$, air flow: $400 \mathrm{~mL} / \mathrm{min}$ ).

Blood analysis: At the end of the feeding period, 3 hours after feeding, 10 cows were selected from each group according to their milk yield, milk compositions, lactation cycle and calving number. Blood sampling was carried out from the jugular vein of cows. The whole blood was subjected to complete blood count (CBC) test using the HM2 (VetScan HM2 Hematology System, Abaxis, Union City, CA, USA). In addition, cortisol levels were measured with commercially available Bovine Cortisol ELISA Test kit (ENDOCRINE TECHNOLOGIES, Inc., Newark, CA, USA) according to the manufacturer's instructions.

\section{Statistical analysis}

The JMP 7.0 (SAS Institute, Cary, NC, USA) program was used for all statistical analyses. Each result is expressed as the mean \pm standard error of the mean. Comparisons between two groups and multiple groups were evaluated using Student's t-test. A probability of less than 0.05 was considered statistically significant.

\section{RESULTS AND DISCUSSION}

Numerous studies were conducted on the effects of essential oil (EO) on rumen microbial fermentation, milk production, and milk composition of dairy cows (e.g., Benchaar et al., 2006; 2007; Yang et al., 2007). The general range of EO was about $0.01 \%$ to $0.04 \%$ of the feed. Study by Benchaar et al. (2007) reported that supplementing the EO mixture at $0.01 \%$ concentration (i.e., $2 \mathrm{~g} / \mathrm{d}$ ) increased the amount of CLA a health-promoting fatty acid in milk. Moreover, the study of Khiaosa-ard and Zebeli (2013) on rumen fermentation variables suggested that EO affected protozoa numbers $(p<0.001)$ but only high doses of $0.02 \%$ of DM had an inhibitory effect on this variable whereas lower doses promoted the number. In this regard, we thought that the appropriate range of EO concentration was $0.01 \%$ to $0.02 \%$. In fact, we found that $0.008 \%$ of the same EO supplement contributed to promotion of CLA in egg yolk in our previous experiment. Based on our previous study, we decided to use double concentration $(0.016 \%)$ that also is between $0.01 \%$ and $0.02 \%$.

\section{Feed intake, milk yield, and composition}

The average feed intake of cows was $37.31 \mathrm{~kg} / \mathrm{d}$. Average DM intake was $23.59 \mathrm{~kg} / \mathrm{d}$ and did not differ for cows fed diets containing phytoncide additive. In addition, there were no remaining feed.

During the 30-day experimental period, no differences between the groups were shown in terms of changes in daily milk yield ( $p>0.05$ ). Milk yield average was $34.3 \mathrm{~kg} / \mathrm{d}$, and was not affected by additives (Table 3). Milk compositions were analyzed at $0 \mathrm{~d}, 10 \mathrm{~d}, 20 \mathrm{~d}$, and $30 \mathrm{~d}$, but there were no differences. Average milk fat and protein concentrations were $4.2 \%$ and $3.1 \%$, respectively, and were unaffected by phytoncide additive (Table 4). In addition, there were no effects on SNF, somatic cells, MUN, betahydroxybutylate and acetone. The 30-day average lactose (lactose) was increased in comparison with the control $(\mathrm{p}<0.05)$, but the small change in the amount of lactose is within the normal range. Therefore, the phytoncide feeding

Table 3. Effect of dietary phytoncide on milk yield in dairy cows ${ }^{1}$

\begin{tabular}{lcc}
\hline \multirow{2}{*}{ Period $(\mathrm{d})$} & \multicolumn{2}{c}{ Milk yield $(\mathrm{kg})$} \\
\cline { 2 - 3 } 0 & $34.6 \pm 0.75$ & $\mathrm{C}$ \\
\hline 0 & $34.0 \pm 1.00$ & $35.1 \pm 1.87$ \\
20 & $34.4 \pm 0.85$ & $35.9 \pm 1.60$ \\
30 & $34.0 \pm 1.11$ & $35.3 \pm 1.37$ \\
$0-10$ & $34.5 \pm 0.88$ & $33.3 \pm 1.52$ \\
$11-20$ & $34.1 \pm 0.86$ & $35.4 \pm 1.57$ \\
$21-30$ & $33.3 \pm 1.11$ & $34.4 \pm 1.29$ \\
$1-30$ & $33.9 \pm 0.90$ & $34.3 \pm 1.49$ \\
\hline
\end{tabular}

${ }^{1}$ Values are expressed as mean \pm standard error of the mean $(n=37)$.

${ }^{2} \mathrm{C}$, control; $\mathrm{T}$, phytoncide $(0.016 \% /$ feed $)$. 
Table 4. Effect of dietary phytoncide on milk composition in dairy cows ${ }^{1}$

\begin{tabular}{lccc}
\hline Item & Day & $\mathrm{C}^{2}$ & $\mathrm{~T}$ \\
\hline Milk fat & 30 & $4.1 \pm 0.17$ & $4.0 \pm 0.12$ \\
$(\%, \mathrm{~kg} / \mathrm{d})$ & & $(1.4 \pm 0.06)$ & $(1.3 \pm 0.04)$ \\
& 1 to 30 & $4.1 \pm 0.09$ & $4.2 \pm 0.10$ \\
& & $(1.4 \pm 0.04)$ & $(1.5 \pm 0.06)$ \\
Milk protein & 30 & $3.1 \pm 0.09$ & $3.1 \pm 0.07$ \\
$(\%, \mathrm{~kg} / \mathrm{d})$ & & $(1.1 \pm 0.03)$ & $(1.0 \pm 0.03)$ \\
& 1 to 30 & $3.1 \pm 0.04$ & $3.0 \pm 0.03$ \\
Lactose & & $(1.1 \pm 0.03)$ & $(1.1 \pm 0.04)$ \\
$(\%, \mathrm{~kg} / \mathrm{d})$ & 30 & $4.8 \pm 0.05$ & $4.8 \pm 0.04$ \\
& & $(1.6 \pm 0.05)$ & $(1.6 \pm 0.05)$ \\
SnF & 1 to 30 & $4.7 \pm 0.02$ & $4.8 \pm 0.03^{*}$ \\
$(\%, \mathrm{~kg} / \mathrm{d})$ & & $(1.6 \pm 0.04)$ & $(1.7 \pm 0.07)$ \\
& 30 & $8.5 \pm 0.09$ & $8.6 \pm 0.08$ \\
& & $(2.9 \pm 0.09)$ & $(2.8 \pm 0.09)$ \\
Somatic cells & 1 to 30 & $8.5 \pm 0.05$ & $8.5 \pm 0.04$ \\
$(1,000 / \mathrm{mL})$ & & $(2.9 \pm 0.08)$ & $(3.0 \pm 0.12)$ \\
MUN & 1 to 30 & $59.0 \pm 8.25$ & $83.7 \pm 28.77$ \\
(mg/dL) & 30 & $134.7 \pm 46.33$ & $136.0 \pm 33.84$ \\
Aceton (mM) & 1 to 30 & $18.2 \pm 0.38$ & $17.7 \pm 0.35$ \\
BHB (mM) & 30 & $0.1 \pm 0.01$ & $0.1 \pm 0.01$ \\
& 1 to 30 & $0.1 \pm 0.01$ & $0.1 \pm 0.01$ \\
& 30 & 0 & 0 \\
SnF, solis & 1 to 30 & 0 & 0 \\
\hline
\end{tabular}

SnF, solids non-fat; MUN, Milk urea nitrogen; BHB, beta-hydroxybutyrate.

${ }^{1}$ Values are expressed as mean \pm standard error of the mean $(\mathrm{n}=37)$, * $\mathrm{p}<0.05$ by Student's $\mathrm{t}$ test.

${ }^{2} \mathrm{C}$, control; T, phytoncide $(0.016 \% /$ feed $)$.

range is not believed to induce a great influence in terms of physiological changes of the cow.

Similarly, supplementation of dairy cows with peppermint at $20 \mathrm{~g} / \mathrm{kg}$ DM had no effect on milk yield and milk composition (Hosoda et al., 2005). A study by Yang et al. (2007) reported that the addition of garlic and juniper berry essential oils to dairy cow diets had no effect on DM intake, milk production or milk composition. In addition, there was no effect on milk performance observed when cows were supplemented with a mixture of EO. This was because these plant extracts did not have any effect on feed intake and ruminal fermentation (Benchaar et al., 2008). Therefore, additive modification of the level and adjustment of feeding term of EO is needed to assess further in vivo experiment.

\section{Fatty acid contents in milk}

Overall, phytoncide supplement in dairy cows showed a significant effect on the milk fatty acid profile (Table 5). Phytoncide treatment increased the milk fat contents of cis9, trans-11 and trans-10, cis-12-CLA compared with the control $(p<0.05)$. The CLA are a family of at least 28 isomers of linoleic acid generally found in the meat and
Table 5. Effect of dietary phytoncide on milk fatty acid contents in dairy cows ${ }^{1}$

\begin{tabular}{|c|c|c|}
\hline $\begin{array}{l}\text { Fatty acids } \\
\text { (\% of total fatty acid) }\end{array}$ & $\mathrm{C}^{2}$ & $\mathrm{~T}$ \\
\hline$\overline{\mathrm{C} 4: 0 \text { (Butryic) }}$ & $1.85 \pm 0.038$ & $1.92 \pm 0.043$ \\
\hline C6:0 (Caproic) & $1.64 \pm 0.037$ & $1.65 \pm 0.044$ \\
\hline C8:0 (Caprylic) & $1.07 \pm 0.042$ & $1.04 \pm 0.052$ \\
\hline C10:0 (Capric) & $2.58 \pm 0.140$ & $2.42 \pm 0.151$ \\
\hline C11:0 (Undecanoic) & $0.25 \pm 0.018$ & $0.23 \pm 0.020$ \\
\hline $\mathrm{C} 12: 0$ (Lauric) & $6.44 \pm 0.239$ & $5.78 \pm 0.148^{*}$ \\
\hline C14:0 (Myristic) & $12.76 \pm 0.281$ & $12.19 \pm 0.268$ \\
\hline C14:1 (Myristoleic) & $0.67 \pm 0.052$ & $0.65 \pm 0.033$ \\
\hline C15:0 (Pentadecanoic) & $0.84 \pm 0.032$ & $0.81 \pm 0.038$ \\
\hline C16:0 (Palmitic) & $29.90 \pm 0.530$ & $29.56 \pm 0.310$ \\
\hline C16:1 (Palmitoleic) & $1.45 \pm 0.091$ & $1.36 \pm 0.037$ \\
\hline C17:0 (Heptadecanoic) & $0.49 \pm 0.007$ & $0.50 \pm 0.014$ \\
\hline C17:1 (cis-10-Heptadecenoic) & $0.09 \pm 0.006$ & $0.11 \pm 0.008$ \\
\hline C18:0 (Stearic) & $14.25 \pm 0.709$ & $15.25 \pm 0.497$ \\
\hline Trans vaccenic acid & $0.66 \pm 0.035$ & $0.73 \pm 0.057$ \\
\hline $\mathrm{C} 18: \ln 9 \mathrm{c}$ (Oleic) & $20.54 \pm 0.503$ & $21.28 \pm 0.511$ \\
\hline C18:2n6t (Linolelaidic) & $0.23 \pm 0.023$ & $0.21 \pm 0.016$ \\
\hline C18:2n6c (Linoleic) & $2.49 \pm 0.110$ & $2.42 \pm 0.076$ \\
\hline C20:0 (Arachidic) & $0.25 \pm 0.009$ & $0.25 \pm 0.007$ \\
\hline C18:3n6 ( $\gamma$-Linolenic $)$ & $0.04 \pm 0.001$ & $0.04 \pm 0.002$ \\
\hline C20:1n9 (cis-11-Eicosenoic) & $0.06 \pm 0.008$ & $0.06 \pm 0.006$ \\
\hline C18:3n3 ( $\alpha$-Linolenic) & $0.36 \pm 0.014$ & $0.36 \pm 0.009$ \\
\hline cis-9, trans-11-CLA & $0.35 \pm 0.016$ & $0.45 \pm 0.020^{*}$ \\
\hline C21:0(Henicosanoic) & $0.04 \pm 0.001$ & $0.04 \pm 0.002$ \\
\hline trans-10, cis-12-CLA & $0.038 \pm 0.0012$ & $0.042 \pm 0.0017^{*}$ \\
\hline C20:2 (cis-11,14-Eicosadienoic) & $0.05 \pm 0.001$ & $0.05 \pm 0.002$ \\
\hline C22:0 (Behenic) & $0.05 \pm 0.002$ & $0.06 \pm 0.004$ \\
\hline $\begin{array}{l}\text { C20:3n6 } \\
\text { (cis-8,11,14-Eicosatrienoic) }\end{array}$ & $0.15 \pm 0.005$ & $0.16 \pm 0.003$ \\
\hline $\mathrm{C} 22: \ln 9$ (Erucic) & $0.09 \pm 0.002$ & $0.08 \pm 0.006$ \\
\hline $\mathrm{C} 20: 4 \mathrm{n} 6$ (Arachidonic) & $0.16 \pm 0.008$ & $0.14 \pm 0.016$ \\
\hline C23:0 (Tricosanoic) & $0.04 \pm 0.001$ & $0.04 \pm 0.002$ \\
\hline C22:2 (cis-13,16-Docosadienoic) & $0.038 \pm 0.0012$ & $0.042 \pm 0.0016^{*}$ \\
\hline $\begin{array}{l}\text { C20:5n3 } \\
\text { (cis-5,8,11,14,17-Eicosatrienoic) }\end{array}$ & $0.040 \pm 0.0013$ & $0.045 \pm 0.0021^{*}$ \\
\hline C24:1n9 (Nervonic) & $0.04 \pm 0.001$ & $0.04 \pm 0.002$ \\
\hline Total \% & 100 & 100 \\
\hline CLA & $0.39 \pm 0.017$ & $0.50 \pm 0.020^{*}$ \\
\hline$\omega 3$ & $0.40 \pm 0.014$ & $0.41 \pm 0.009$ \\
\hline$\omega 6$ & $3.07 \pm 0.102$ & $2.97 \pm 0.081$ \\
\hline$\omega 6 / \omega 3$ & $7.72 \pm 0.190$ & $7.25 \pm 0.115^{*}$ \\
\hline
\end{tabular}

dairy products derived from ruminants. Food products from grass-fed ruminants are good sources of CLA (Dhiman et al., 2000). Healthy functional fatty acid CLA is a material with diverse physiological activities. It has been attributed with many beneficial effects in the prevention of atherosclerosis, different types of cancer and hypertension, and is also known to improve immune function (Bhattacharya et al., 2006). Benchaar et al. (2007) reported 
no change in milk fatty acid profile when cows were supplemented daily with $750 \mathrm{mg}$ of mixture of essential oil. However, supplementing the same mixture at a higher concentration (i.e., $2 \mathrm{~g} / \mathrm{d}$ ) increased the concentration of CLA, a health-promoting fatty acid, in milk fat (Benchaar et al., 2006). In our trial, though a small amount was added to the feed, CLA content of the milk was increased.

Among the different rumen bacteria, Butyrivibrio fibrisolvens can produce significant amounts of cis-9, trans11 CLA from the linoleic acid in rumen, and cis-9, trans-11 CLA is transported to the mammary glands (Kim et al., 2000; Wang and Lee, 2015). CLAs produced in the rumen are significantly affected by diet. Linoleic acid is a major source of CLA, which is mostly found in plant oil. Thus, supplying these oilseeds can improve cis-9, trans-11 CLA content in milk (Wang and Lee, 2015). Furthermore, CLA isomers in the rumen are synthesized through various mechanisms. The other cis-9, trans-11 CLA is de novo synthesized from trans-11 vaccenic acid (TVA) in the mammary gland (Griinari et al., 2000; Corl et al., 2001; Kay et al., 2004). Stearoyl-CoA desaturase ( $\Delta 9$-desaturase) is an important enzyme that plays a key role in cis-9, trans11 CLA synthesis from TVA in the mammary gland (Griinari et al., 2000; Corl et al., 2001; Kay et al., 2004; Wang and Lee, 2015). Therefore, additional research on the synthesis of CLA in the rumen and mammary gland by phytoncide is required.

In addition, eicosapentaenoic acid (EPA) content of the phytoncide treated group was significantly higher than that of the control. Accordingly, $\omega 6 / \omega 3$ fatty acid ratio was decreased $(p<0.05)$ (Table 5). EPA is a precursor of docosahexaenoic acid (DHA), and DHA is one of the fatty acids of special interest because of its importance in brain and retinal neonatal development (Connor, 2000). The ratio of $\omega 6 / \omega 3$ fatty acids has a valuable influence on dairy products because a low $\omega 6 / \omega 3$ ratio is more desirable in reducing the risk of many chronic diseases (Simopoulos, 2010; Abarghuei et al., 2014). Abarghuei et al. (2014) showed that the addition of pomegranate-peel extract decreased $\omega 6 / \omega 3$ ratio in cow's milk. The increase of the long-chain $\omega-3$ fatty acid such as EPA, DHA could be due to desaturation and elongation of $\alpha$-linolenic acid (ALA, C18:3n3). ALA and EPA converted to its elongated metabolite DHA, and then deposited it in the milk. Given that humans seem to have a limited ability to desaturate the last step of the formation from ALA, milk can be considered a useful dietary source of such fatty acids (Baucells et al., 2000; Carrillo-Dominguez et al., 2005).

In general, essential oil has an antibacterial activity against gram-negative and positive bacteria (Helander et al., 1998). Several gram bacteria are involved in the ruminal bio-hydrogenation of unsaturated dietary fatty acids (Harfoot and Hazlewood, 1997). Therefore, feeding essential oil could lower the number and the activity of rumen bacteria involved in the bio-hydrogenation of unsaturated fatty acids. This means that the inhibition of ruminal bio-hydrogenation or ruminal bacteria activity by phytoncide metabolites could have produced higher unsaturated fatty acids from rumen to milk.

In addition, saturated fatty acid, C12:0 were lower in the milk of phytoncide treated group compared with the control $(\mathrm{p}<0.05)$. Similarly, the reduction of saturated fatty acid in milk is very helpful to the health of humans who drink milk, because dietary saturated fat intake has been associated with an increased risk of cardiovascular disease (Siri-Tarino et al., 2010). These results are considered to indicate that the phytoncide feed additives may provide benefits for the production of milk, and would ultimately promote a better fatty acid composition for the human diet.

\section{Complete blood count}

The result of $\mathrm{CBC}$ analysis in whole blood is presented in Table 6. Phytoncide treatment did not affect white blood cells, red blood cells, hemoglobin, hematocrit, mean corpuscular volume, mean corpuscular hemoglobin or mean corpuscular hemoglobin concentration compared to the control group. This result is considered to indicate that feed with added phytoncide does not induce any disease-related chemical changes in dairy cows.

\section{The level of cortisol in serum}

In blood analysis, cortisol levels of the group that received phytoncide treatment were significantly decreased compared to the control in dairy cows after 30 days $(\mathrm{p}<0.05)$ (Figure 1). The normal range of blood cortisol concentration is 1 to $17 \mathrm{ng} / \mathrm{mL}$ in dairy cows (Lefcourt et al., 1993). In our first test, cortisol concentration averaged

Table 6. Effect of dietary phytoncide on complete blood count analysis in dairy cows ${ }^{1}$

\begin{tabular}{lcc}
\hline Item & \multicolumn{1}{c}{$\mathrm{C}^{2}$} & \multicolumn{1}{c}{$\mathrm{T}$} \\
\hline WBC, 4 to $12 \mathrm{~K} / \mu \mathrm{L}^{3}$ & $8.67 \pm 0.57$ & $10.15 \pm 0.68$ \\
Lymphocyte, 2.5 to $7.5 \mathrm{~K} / \mu \mathrm{L}$ & $5.62 \pm 0.45$ & $6.67 \pm 0.39$ \\
Monocyte, 0 to $0.84 \mathrm{~K} / \mu \mathrm{L}$ & $0.78 \pm 0.09$ & $0.97 \pm 0.07$ \\
Granulocyte, 0.6 to $6.7 \mathrm{~K} / \mu \mathrm{L}$ & $2.33 \pm 0.19$ & $2.41 \pm 0.42$ \\
RBC, 5 to $10 \mathrm{M} / \mu \mathrm{L}$ & $6.41 \pm 0.23$ & $6.44 \pm 0.24$ \\
Hemoglobin, 8 to $15 \mathrm{~g} / \mathrm{dL}$ & $11.81 \pm 0.37$ & $11.86 \pm 0.35$ \\
Hematocrit, $24 \%$ to $46 \%$ & $30.20 \pm 0.68$ & $30.47 \pm 0.84$ \\
MCV, 40 to $60 \mathrm{fL}$ & $47.40 \pm 1.28$ & $47.70 \pm 1.45$ \\
MCH, 11 to $17 \mathrm{pg}$ & $18.63 \pm 0.85$ & $18.37 \pm 0.52$ \\
MCHC, 30 to $36 \mathrm{~g} / \mathrm{dL}$ & $39.19 \pm 1.30$ & $38.60 \pm 0.82$ \\
Platelet, 100 to $800 \mathrm{~K} / \mu \mathrm{L}$ & $203.40 \pm 26.52$ & $177.40 \pm 13.92$
\end{tabular}

WBC, white blood cell; RBC, red blood cell; MCV, mean corpuscular volume; $\mathrm{MCH}$, mean corpuscular hemoglobin; $\mathrm{MCHC}$, mean corpuscular hemoglobin concentration.

${ }^{1}$ Values are expressed as mean \pm standard error of the mean $(n=10)$.

${ }^{2} \mathrm{C}$, control; T, phytoncide $(0.016 \% /$ feed $)$.

${ }^{3}$ Normal range. 


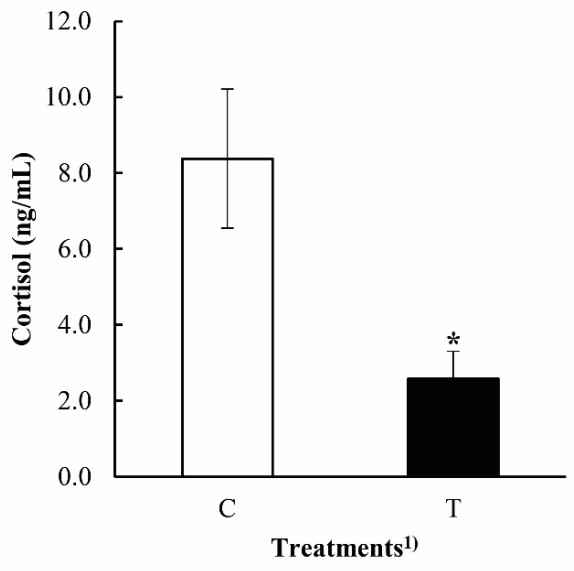

Figure 1. Effect of dietary phytoncide on level of serum cortisol in dairy cow. Values are expressed as mean \pm standard error of the mean $(\mathrm{n}=10),{ }^{*} \mathrm{p}<0.05$ by Student's t-test. ${ }^{1} \mathrm{C}$, control; $\mathrm{T}$, phytoncide $(0.016 \%$ /feed $)$.

$6.2 \pm 2.13 \mathrm{ng} / \mathrm{mL}(\mathrm{C})$ and $7.2 \pm 2.05 \mathrm{ng} / \mathrm{mL}(\mathrm{T})$, and then $8.4 \pm 1.83 \mathrm{ng} / \mathrm{mL}$ (C) and $2.6 \pm 0.74 \mathrm{ng} / \mathrm{mL}$ (T) after experiment. Values did not exceed basal cortisol levels. Cortisol has been used mainly as a key indicator of the stress response in cows. A high cortisol level may produce negative effects and may down-regulate some functions such as eating, growth, and reproduction (Burnett et al., 2014). Chrousos (2009) reported that elevated cortisol concentration is a risk factor for chronic stress that can cause additional behavioral and somatic disorders. In our research, it was found that phytoncide relieved the negative effects of plasma cortisol in cows. These findings indicate that a phytoncide supplement decreased stress hormone levels, which may partially contribute to immune activity (Li, 2010). Ultimately, this will lead to more optimal productivity and health of dairy cows.

\section{CONCLUSION}

The results of this study showed that feeding of essential oils had no effect on milk yield and composition, and thus it is determined that phytoncide will not cause significant physiological changes in cows. However, positive effects were seen in the fatty acids content in milk, as the functional fatty acids (CLA and EPA) and $\omega 3 / \omega 6$ ratio were increased in the treated group. Furthermore, cortisol, a stress hormone, significantly decreased in serum of cows fed phytoncide additives. Taken together, these data indicate that phytoncide is a potential feed additive for improving milk fatty acid and promoting healthy functional milk production in dairy cows.

\section{CONFLICT OF INTEREST}

We certify that there is no conflict of interest with any financial organization regarding the material discussed in the manuscript.

\section{ACKNOWLEDGMENTS}

This research was supported by the Agricultural Biotechnology Development Program (313120-04), Korea Institute of Planning and Evaluation for Technology in Food, Agriculture, Forestry and Fisheries, Republic of Korea.

\section{REFERENCES}

Bhattacharya, A., J. Banu, M. Rahman, J. Causey, and G. Fernandes. 2006. Biological effects of conjugated linoleic acids in health and disease. J. Nutr. Biochem. 17:789-810.

Burnett, T. A., A. M. L. Madureira, B. F. Silper, A. Nadalin, A. Tahmasbi, D. M. Veira, and R. L. A. Cerri. 2014. Short communication: Factors affecting hair cortisol concentrations in lactating dairy cows. J. Dairy Sci. 97:7685-7690.

Carrillo-Dominguez, S., M. E. Carranco-Jauregui, R. M. CastilloDominguez, M. I. Castro-Gonzalez, E. Avila-Gonzalez, and F. Perez-Gil. 2005. Cholesterol and n-3 and n-6 fatty acid content in eggs from laying hens fed with red crab meal (pleuroncodes planipes). Poult. Sci. 84:167-172.

Chrousos, G. P. 2009. Stress and disorders of the stress system. Nat. Rev. Endocrinol. 5:374-381.

Concha, C., S. Hu, and O. Holmberg. 1996. The proliferative responses of cow stripping milk and blood lymphocytes to pokeweed mitogen and ginseng in vitro. Vet. Res. 27:107-115.

Connor, W. E. 2000. Importance of n-3 fatty acids in health and disease. Am. J. Clin. Nutr. 71:171S-175S.

Corl, B. A., L. H. Baumgard, D. A. Dwyer, J. M. Griinari, B. S. Phillips, and D. E. Bauman. 2001. The role of delta (9)desaturase in the production of cis-9, trans-11 cla. J. Nutr. Biochem. 12:622-630.

Dhiman, T. R., L. D. Satter, M. W. Pariza, M. P. Galli, K. Albright, and M. X. Tolosa. 2000. Conjugated linoleic acid (CLA) content of milk from cows offered diets rich in linoleic and linolenic acid. J. Dairy Sci. 83:1016-1027.

Folch, J., M. Lees, and G. H. Sloane Stanley. 1957. A simple method for the isolation and purification of total lipides from animal tissues. J. Biol. Chem. 226:497-509.

Griinari, J. M., B. A. Corl, S. H. Lacy, P. Y. Chouinard, K. V. V. Nurmela, and D. E. Bauman. 2000. Conjugated linoleic acid is synthesized endogenously in lactating dairy cows by delta (9)desaturase. J. Nutr. 130:2285-2291.

Harfoot, C. G. and G. P. Hazlewood. 1997. Lipid metabolism in the rumen In: The Rumen Microbial Ecosystem (Eds. P. N. Hobson and C. S. Stewart). Springer, Netherlands. pp. 382-426.

Helander, I. M., H. L. Alakomi, K. Latva-Kala, T. MattilaSandholm, I. Pol, E. J. Smid, L. G. M. Gorris, and A. von Wright. 1998. Characterization of the action of selected essential oil components on gram-negative bacteria. J. Agric. Food Chem. 46:3590-3595.

Hosoda, K., T. Nishida, W. Y. Park, and B. Eruden. 2005. Influence of mentha $\times$ piperita L. (peppermint) supplementation on nutrient digestibility and energy metabolism in lactating dairy cows. Asian Australas. J. Anim. Sci. 18:1721-1726. 
Igal, R. A. 2011. Roles of stearoylCoA desaturase-1 in the regulation of cancer cell growth, survival and tumorigenesis. Cancers 3:2462-2477.

Kay, J. K., T. R. Mackle, M. J. Auldist, N. A. Thomson, and D. E. Bauman. 2004. Endogenous synthesis of cis-9, trans-11 conjugated linoleic acid in dairy cows fed fresh pasture. J. Dairy Sci. 87:369-378.

Khiaosa-ard, R. and Q. Zebeli. 2013. Meta-analysis of the effects of essential oils and their bioactive compounds on rumen fermentation characteristics and feed efficiency in ruminants. J. Anim. Sci. 91:1819-1830.

Kim, Y. J., R. H. Liu, D. R. Bond, and J. B. Russell. 2000. Effect of linoleic acid concentration on conjugated linoleic acid production by butyrivibrio fibrisolvens A38. Appl. Environ. Microbiol. 66:5226-5230.

Lee, Y. and J. P. Vanden Heuvel. 2010. Inhibition of macrophage adhesion activity by 9 trans, 11 trans-conjugated linoleic acid. J. Nutr. Biochem. 21:490-497.

Lefcourt, A. M., J. Bitman, S. Kahl, and D. L. Wood. 1993. Circadian and ultradian rhythms of peripheral cortisol concentrations in lactating dairy cows. J. Dairy Sci. 76:26072612.

Li, Q. 2010. Effect of forest bathing trips on human immune function. Environ. Health Prev. Med. 15:9-17.
Moloney, F., S. Toomey, E. Noone, A. Nugent, B. Allan, C. E. Loscher, and H. M. Roche. 2007. Antidiabetic effects of cis-9, trans-11-conjugated linoleic acid may be mediated via antiinflammatory effects in white adipose tissue. Diabetes 56:574582.

NRC (National Research Council). 2001. Nutrient Requirements of Dairy Cattle. 7th rev. edn. National Academy Press, Washington, DC, USA.

Simopoulos, A. P. 2010. Genetic variants in the metabolism of omega-6 and omega-3 fatty acids: their role in the determination of nutritional requirements and chronic disease risk. Exp. Biol. Med. 235:785-795.

Siri-Tarino, P. W., Q. Sun, F. B. Hu, and R. M. Krauss. 2010. Saturated fat, carbohydrate, and cardiovascular disease. Am. J. Clin. Nutr. 91:502-509.

Wang, T. and H. G. Lee. 2015. Advances in research on cis-9, trans-11 conjugated linoleic acid: A major functional conjugated linoleic acid isomer. Crit. Rev. Food Sci. Nutr. 55:720-731.

Yang, W. Z., C. Benchaar, B. N. Ametaj, A. V. Chaves, M. L. He, and T. A. McAllister. 2007. Effects of garlic and juniper berry essential oils on ruminal fermentation and on the site and extent of digestion in lactating cows. J. Dairy Sci. 90:56715681 . 